\title{
A Review of Research on University Presidents Selection System in Recent Ten Years
}

\author{
Fan Yanhua ${ }^{1}$, Yu Qing ${ }^{2}$ \\ ${ }^{1}$ Department of Human Resource Management, Jiangsu University, Zhenjiang, China \\ ${ }^{2}$ Department of Teacher Education, Jiangsu University, Zhenjiang, China
}

Email address:

2716138604@qq.com (Fan Yanhua)

\section{To cite this article:}

Fan Yanhua, Yu Qing. A Review of Research on University Presidents Selection System in Recent Ten Years. Science Journal of Education. Vol. 7, No. 3, 2019, pp. 65-72. doi: 10.11648/j.sjedu.20190703.11

Received: May 26, 2019; Accepted: July 10, 2019; Published: July 30, 2019

\begin{abstract}
Double First-Class" construction needs first-class university presidents. The standardized system of selecting and appointing university presidents can promote excellent university presidents and promote their professional development. This paper is to review the selection system of university presidents in recent ten years from 2007 through analyzing comprehensively the research of selecting standards, selecting methods and the program and tenure by literature analyzation. The research of selecting standards includes studying their personal characteristics, educational background, working experience and decision-managing abilities. The research of selecting methods is mainly from the perspective of country reference, which can be summarized in the following three: the selection system represented by the USA and Britain, the twostage system represented by Japan and European countries and the central appointment system represented by our country. The research of the tenure of university presidents mainly focuses on the employment period and relative factors which influence the tenure. It turns out that the selecting standards of the university presidents in our country are to be improved; the selecting methods and program lack flexibility; the tenure is comparatively short; and the degree of specialization is to beehanced compared with other countries.
\end{abstract}

Keywords: University President, Selection System, Specialization, "Double First-Class" Construction, Review

\section{Introduction}

With the development of "double-first-class" construction in China, the construction of first-class universities is becoming more and more urgent. Judging from the development experience of top universities abroad, the development of first-class universities is closely related to the selection of their principals. The university president, as a leading figure of a university, is increasingly showing a tendency to specialization. The so-called principal specialization, also known as the principal professional development, refers to the professional knowledge, professional attitude and professional ability, which is constantly renewing, evolving and enriching [1]. The realization of the Headmaster's specialization not only relies on the professional qualification, the macro-management of the conditions of selection, but also the guarantee of rigid elective system. Therefore, it is of great significance to make clear the current research status of the university president selection system, to promote the professional accomplishment of the headmaster group, to improve the professionalization of the university presidents and to meet the "double-first-class" construction.

In the CNKI Academic library of China, with the university president and selection as the article name, for fuzzy retrieval of documents from January 1, 2007 to December 20, 2017 in the literature search term, a total of 83 records were retrieved, including 9 doctoral theses, 62 journal papers. It can be seen that in the past ten years, the research on the selection and appointment system of university presidents has been in-depth, but only in 2013, there is a summary article, for 2014 till now, the study has not been involved, so in order to clarify the status of the university president election system, it is necessary to make a review of the literature of the past ten years. 


\section{Method}

\subsection{Study on the Criteria for Selecting}

The primary task of the appointment of university presidents is to determine the selection criteria, so the selection criteria are the determinants of the selection of university presidents. According to the literature of recent ten years, research has been carried out mainly from the research of personal characteristics, educational background, work experience and the decision-making and management ability of university presidents.

\subsubsection{A Study on the Personal Characteristics of University Presidents}

As for the personal characteristics of university principals, the empirical research method is widely used. Mainly includes three aspects such as gender and age, place of origin and nationality and political appearance and administrative level.

Gender and age. Through the empirical analysis of the gender and age characteristics of American University presidents, Guo Jun etc, the study finds that the principal of American University is dominated by middle-aged male whites, [2]. On the basis of statistical investigation on the principals of our country's undergraduate universities, Zhang Yingqiang etc. [3], find that the presidents of Chinese universities are more than 50-year-old males; According to the current principals of the "211 Project" Hundred Universities, Li Qiaozhen finds that the majority of these university principals are men with an average age of 56 years [4]. Through the calculation found that "985 project", Xie Qing find the average age of the current school principals is 55.38 years old. The average age of current school in "211 Project" principals is 54.45 years old, and the majority is males [5].

Native and National. Through an empirical study on the principals of "985 project" in China, Li Zhongwei finds that the presidents of these universities mainly came from middle and small cities in the East and Mid-west [6]. From the national point of view, the President of the Han nationality occupies the main position, only 1 of the Manchu nationality. As far as the relationship between place of origin and the location of university is concerned, most principals belong to different positions. Based on the background of history, the empirical study of American University presidents, Guo Jun etc. [2], Find that the proportion of American minority principals in 2011 increased from $8.1 \%$ in 1986 to $12.6 \%$, indicating that the principals ' sources are becoming more diversified.

Administrative level and political appearance. By comparing the presidents of Chinese and American universities, Li Qiao Zhen found that American university principals have a relatively single status and no administrative level, and that our university presidents have administrative levels [4]. In addition, she also conducted empirical research on the current "211 Project". Hundred University presidents, found that the new principal part, the proportion of party members declined slightly, but still the majority of CPC membership. Li Zhongwei study found that the "985 project" university president only 2 are independent, the rest are party members, and also the Deputy Secretary of the party committee, reflects the CPC's leadership at the university's core position. Overall, the majority are CPC members [4].

The above study shows that at present, the number of university presidents is mostly middle-aged men, mainly from the eastern and western small cities in China Han people, and the majority of CPC members, with corresponding administrative level. However, with the increasing trend of the administration of principals in China, many problems have been raised. Therefore, many studies suggest that the university presidents should carry out the reform of elective system and implement the reform of "deadministration" to promote the professional development of principals.

\subsubsection{Research on the Educational Background of University Presidents}

As an important aspect of the selection criteria, the university Presidents' educational background mainly includes graduation school, academic background, international level and academic ability.

Graduate school, education and subject background. Through the study and analysis of the presidents of foreign famous universities, Wu Jian finds that most of the foreign famous university presidents graduated from the international and diversified universities, and they have a high degree, and have diversified knowledge structure and humanistic background [7]. In his dissertation, Li Ping find that American public research universities tend to have a number of educational experiences in which university candidates have advanced education in many prestigious universities, and must have a doctorate degree, which requires a multidisciplinary background [8]. The President of the National University of Japan has a "remarkable plot" and is inclined to graduate from prestigious universities and must have a high degree of education.

The above study found that foreign universities attach great importance to the educational background of university presidents. Looking back in the domestic: in the study of 115 "211 Engineering" universities, Guo Jun find that the presidents of China's universities are mostly academic elites with $\mathrm{PhD}$ degree in science and technology, with the title of Bo-guide, but lack of knowledge background of humanities and social science, and lack of theory of higher education management [9].

Internationalization level. With the advancement of globalization and the development of colleges and universities, university presidents should have an international background and broaden their horizons. Taking 115 "211 project" university presidents as an example, Guo Jun etc. [2], studied the academic background of Chinese university principals, and suggested that we should pay attention to the study background and international vision of 
the famous universities in the process of selecting principals. Guo Jun also analyzed the characteristics of American University principals, found that most of the principals have overseas study experience, in addition, he also focused on the history of higher education in the United States a number of outstanding students to Germany to learn the concept of advanced school principals [2].

Academic research capabilities. As a leading figure of the university, its academic activities and academic achievements fully reflect the academic influence of university presidents in the world. Zhu Jian selected 5 British different types of universities, using the text analysis method, the 5 university principals in the recruitment notice of the qualifications in the interpretation, the study found that 5 of the university principals in the qualifications required to pay attention to the academic background of the headmaster [10]. Using the same method, Wang Zhanjun etc. [11], on the basis of the interpretation of the six famous universities in the United States, pointed out that American universities tend to select principals from academic elites, and American universities attach great importance to the academic background of principals. Li Ping's study found that the Japanese university presidents must have strong teaching research ability, should be the subject leader in their professional field, and have certain academic attainments [8]. Taking 115 "211 Engineering" colleges and universities as the research object, Guo Jun has studied the university president's educational academic background, has analyzed the academic background of our country university president, and has put forward the corresponding suggestion: emphasizes that the university president of our country should pay attention to its higher education discipline accomplishment [9].

University presidents, as academic leaders, should have a professional knowledge base, reflecting their high standards, especially in today's "double-first-class" Construction of the trend, to become academic leaders, scientific research "leader", leading the whole school teachers and students in the international arena to build first-class disciplines, to carry out first-class academic research, output first-class results. Open education vision, international level, can correct the professional attitude of the university President, to the correct positioning of the university, the development of the characteristics of the institutions themselves. Rich expertise and ability, broad international perspective, high level of academic attainments together constitute the requirements of education, can jointly promote the professional development of university principals, for the university to build their own characteristics of the first-class schools and first-class disciplines to provide support.

\subsubsection{Research on the Work Experience of University Presidents}

For the work experience, the scholars mainly study the principal's former Office unit. Towards to the world's top 70 university presidents analysis, Ren Zhen found that foreign university presidents have been employed in universities the largest proportion of people, most of the principals have worked in many universities, has a wealth of education management experience [12]. Wang Min [13], who conducted a career background study on the current president of Taiwan's public university, found that the president of the current university in Taiwan had been working in universities, scientific research units or government departments before serving as principal, but it was distinctly different from the principals of the mainland universities that the president of Taiwan University had seldom served as vice-Chancellor before his appointment. This suggests that Taiwan is asking for more dollars for the work experience of university presidents. Taking 115 " 211 " university presidents as an example of the professional background of Chinese university presidents, Shang Guanjun find that: most of the university presidents from the university system, has served as Vice-President, overseas work experience, in various organizations in the social positions, half of the university principals have worked in other schools experience [14]. This shows that the professional experience of university presidents in China is relatively single. All in all, for the selection of excellent university principals, rich work experience can increase social experience, exercise the president's practical ability, help to achieve the professionalization of the university principals, to achieve stable operation of the university.

\subsubsection{Research on the Decision-making and Management Ability of University Presidents}

Zhong Binglin etc. [15], through analyzing the selection mechanism of world-class universities, it is found that the presidents of world-class universities should have a keen planning ability and outstanding administrative ability. Li Ping has found that American universities attach great importance to efficiency in selecting candidates, and they emphasize their administrative experience and corporate management experience, while the National University of Japan emphasizes the candidate's academic ability and requires a strong professional achievement [8]. Liu Weina [16], compared the criteria of university presidents selection on both sides, it was found that the presidents of Taiwan University should have both academic and managerial abilities, so that they could help each other and complement each other to enhance the headmaster's ability to lead the university towards success. Qian Peizhong, Li Yingying's article elaborated our country after reform and opening, mainly is the expert management type headmaster to take charge of the university [17]. Based on the above research, the university president should have excellent management and decision-making ability, do well the overall layout and planning of the school, and better lead the development of the university.

\subsection{Study on the Mode and Procedure of Selection}

In the past ten years, the selection of university presidents is divided into three categories, mainly including the United States and the United Kingdom, the selection of two- 
paragraph system based on Japan and continental Europe, and the central appointment system based on our country.

\subsubsection{Research on the Selection System}

The United States. The American President selection system is a more mature selection method. Ji Chengjun said the selection system of American principals is the independent selection of schools under the leadership of the board of Directors [18]. Each university has its own independent board of directors, mainly by appointing principals to exert influence on schools. Usually when the school principal is vacant or is about to be vacant, the school board will open the selection of candidates, and the selection process will usually take months or even more than a year. Tang Jian etc. [19], introduces the selection system of American University presidents, summarizes the basic characteristics of openness, fairness and competition in the selection system of American university presidents, and is a more mature and effective selection system. Similarly, Li Qiaozhen carried out an analysis of the selection system for American University presidents, and she believes that the selection of American university presidents is characterized by "fit, active participation and diversity", and she values the diversity of subjects involved in the selection process [4]. Mao Lingling, Chen Yan, Fu Lianxing, Li Feng, Ge Changna, Yin Hongfang etc. The thesis also studies the selection system of American University presidents, and expounds the specific methods and selection procedures of American university presidents selection. Unlike the above-mentioned scholars, Xiong Wanxi uses field research methods to deeply study the American University President selection system [20]. In addition, he interviewed Harvard University's former headmaster Derek BOK through interviews, and introduced the experience and practice of the selection of presidents of top universities in the United States. The difference is that he introduced the 2003 Boston University failure selection case, and the 2004 Massachusetts Institute of Technology success cases [21], through a case study, revealing the main drawbacks of the selection system: interference with the selection of university presidents. The selection and appointment of excellent university presidents, along with the continuous development and perfection of the American selection system, have also promoted the process of the professionalization of the university presidents.

United Kingdom. The Chancellor of the United Kingdom is only an honorary title, having the right to be a permanent member of the British royal family or the dean of Independent colleges. The Vice-chancellor is actually the supreme leader of the school and has great power. In Jin Yuanyuan's study, his integrated the selection of the viceChancellor of the British university into a governmentmandated + school-independent selection system, and divided the selection and appointment process of the ViceChancellor into five steps. Unlike Jin Quanyuan, Qi Pinwei focuses on the composition of the board of Directors of the British University selection and the principal functions of the principal after his appointment [22]. Ming Xin [23], and
Chen Wei [24], respectively compared the British and American University Presidents selection method, found a lot in common: the selection of a broad team, the selection of flexible standards, professors and so on.

The United States and the United Kingdom as the representative of the principal selection system, generally speaking, has the following characteristics: The government does not intervene in the selection of principals, the selection process with a wide range of democracy, and the selection process of transparency and impartiality. Although there is a slight difference in the specific selection criteria and procedures, the overall selection process is dominated by democratic, open and comprehensive screening methods.

\subsubsection{Study on Election and Appointment of Two-term System}

Japan and the Continental European countries adopted the election and the appointment of a two-paragraph system to determine the candidate of the university president, that is, the final decision of the president selection depends on the number of staff or professors election votes, the decision is then appointed by the government.

Japan. There is a long system inside the University of Japan, and the headmaster has great power. Jin Quanyuan's Research found that Japanese university presidents are selected by faculty, students, alumni and many other parties. In Fu lianxing's study [25], he think that the management decision-making organization of Japanese universities is the "Council of the University" and the "Professor meeting" of the Faculties, the Institute, or the "committee" of the relevant departments. The "Professor" will determine the criteria for the selection of principals, decide on the term of office of the headmaster, vote for the headmaster, and appoint the Ministry of message. The study of the principal selection organization is mainly on these two aspects, and the study of the procedure of Japanese University president selection, from Chen Yan and Ji Chengjun's research, the Japanese university president mainly through the selection of the way to produce, including the written test and interview two parts. The Council or school-level professors will elect candidates on the basis of the results of the comprehensive indicators, which are then elected by secret ballot by the whole faculty and then appointed by the Ministry of Culture. [26]

European countries. The selection system of university presidents in continental European countries from Zhong Binglin etc. [27], is called the selection of university presidents under the government's authority, which is chosen by the government to form a selection committee or an academic council formed by the school, and the selected principal candidate is eventually appointed by the government. In addition, he gave a detailed introduction to the selection procedures of the French higher Normal School and the rector of the University of Berlin in Germany. Ji Chengjun mentioned in his study that the president of France was elected directly by the Council [18], which consisted of teachers, students, administrators and outside people, and $\mathrm{Fu}$ Lianxing found that the French Government had recruited all 
the professors and lecturers of the university as National servants [25]. However, the power to elect a headmaster to the University Council, the implementation of academic autonomy. Scholars in the European continental countries in the selection of university presidents, concentrated in France, a typical centralized state, through the study of French President selection to reflect the overall situation of the European continent. While Sun Jin chose Germany's Heidelberg University as a case study of the university President selection system [28], unlike in France, the study showed that Heidelberg university used different institutions to be responsible for the selection and appointment of the university principals, the selection committee of the Board of Trustees, the Council of the University and the state Government for selection and nomination. The University Council is responsible for the elections, the councils and the State Department of Science are accredited and the Governor is appointed. This division of labor, a clear mandate of the University President selection mechanism to help ensure the different groups of democratic participation in decisionmaking. Ma Huaide is different from the above-mentioned scholars in the selection of subjects, he selected several wellknown university presidents to discuss the selection system of European universities as an example of the European atypical countries such as Spain, Switzerland and Italy [29]. The study shows that the university presidents of these European countries are elected directly or indirectly by all teachers and students, which fully embodies the principle of the selection of teachers ' will, openness, transparency and full competition.

According to the analysis of the two-paragraph system of university presidents ' election in France and Japan, we can see that this two-stage selection system can not only guarantee the open and impartial selection process, but also accord with the internal development plan of the school.

\subsubsection{The Study of Appointment System}

Appointment system is the central administrative appointment system, and the selection of university presidents in China is a typical appointment system. In Zhang Jinwei's research, he points out that the selection method of university presidents in China is essentially the selection method of the traditional administrative leading cadres. The choice of the headmaster belongs to the Senior Cadre selection procedure, has the strict organization process. The usual step is "the superior party Committee organizes the first person to carry on the mapping, organizes some opinion poll activity and the small scope recommendation activity, provides the reference for the competent leader, but the final decision person is the superior leader." [30]

In a comprehensive way, the research on the selection and appointment system of university presidents in China mainly involves the present situation and reform. The empirical investigation and analysis on the current situation of the selection system of university presidents in China mainly includes Zhang Yingqiang etc. [31] The analysis of the group characteristics of the university principals in 759 universities in China. Chen Yan from the perspective of globalization that our university presidents are the authority of the academic field, the decision-maker of administrative affairs [32]. Yao Jinju explains and analyzes the openness of the selection information of university presidents in China based on the legal perspective [33]. Through Xu Guodong's article [34], he points out the drawbacks of the central appointment system of university presidents in China: To strengthen the bureaucracy of universities, to select the narrow field of vision and to lose democracy, and to put forward the construction of selection mechanism. In view of these shortcomings, The pilot study of Zhang Jinwei on the open selection of university presidents in China, and further proposed that our country should be open to select and design a reasonable selection procedure [30]. Yang Xinglin [35], from the three emphasis on the angle: first, the use of evaluation perspective to examine the views of the university President selection; second, the use of reference perspective to operate the selection of university principals in China; Thirdly, the choice of principal selection strategy by the perspective of reality, only three organically combined, We can really ensure the smooth conduct of the reform of the selection system. Pan Xiaojie [36], from the perspective of the relationship of principal-agent, this paper studies the reform of our country's headmaster selection system, and puts forward to improve the system of selecting university presidents in China based on the principal-agent theory framework, which needs to reduce the principal-agent hierarchy and improve the information cost. Lin Zhaohong [37], based on the mixed view of higher order theory and competency model, forecasts the trend of the selection and appointment mechanism of university presidents.

No matter the status quo of the appointment system, the problem analysis or the reform trend of research, all reflect the Chinese president selection system needs to be perfected. In view of the defects of appointment system, our country has carried out the pilot of open selection, and it is a very urgent task to reform our country's appointment system of university President by reference to the mature experience. To promote efficient and orderly development of the university in the continuous exploration and reference in the gradual realization of the professional development of the university principals in China, and better lead the "doublefirst" construction.

\subsection{Tenure Research}

\subsubsection{Deration of Tenure}

Zhang Xin etc. [38], using the method of empirical analysis find that the average term of office of American University presidents is 22.4 years, of which the shortest is 8 years and the longest term is 43 years. Wang Min [13], by studying the tenure of university presidents in Taiwan, found that although there was a legal age for the presidency of the Taiwanese university, there was a certain degree of flexibility in the process of specific tenure. In addition, Yu Xinan and Liu Xiuli [39], compared the tenure of university presidents in China and the United States, and found that the tenure of 
Chinese university presidents was generally lower than that of American university presidents, with Chinese university presidents serving for an average of 4.1 years and 12.2 years in the United States. Liu Siliang [40], studied the group characteristics of the outgoing principals of the nine School union, and divided the term of office of Principals into three categories of long term, medium term and short term, and calculated an average term of 7.5 years, thus explaining that the term of the nine School union principals was relatively stable. However, in the same way, Chen Yinyin [41], by studying the presidency of 985 universities in China in the past 30 years, also proves that Chinese university presidents have a short term, but he thinks that the reason is that administrative changes lead to frequent change of tenure, which leads to the unstable term of university presidents. Overall, the appointment time of Chinese university presidents is short, short term is not enough to carry out the long-term development plan of the headmaster, hinder the long-term stable development of the university, and it is difficult to implement the construction plan of "double-firstclass".

\subsubsection{Study on the Influential Factors of Tenure}

Selection method. Zhang Xin etc. [38], through the analysis of the presidency of the American Research University, it is believed that the selection system can influence the tenure of the university President, and the Board of Directors of the American University will generally be employed for the performance of the principals, thus saving part of the expenses of recruiting principals. Yu Xinan in his research, the analysis leads to the "short-lived" "Life Gate" of Chinese university presidents is too unitary public university running mode and administrative education management system. The development of higher education in China is dominated by the government, and the Government stipulates the tenure of the university presidents, which leads to the lack of necessary flexibility in the tenure of principals [42]. Scholars such as Wang Fei and Chen Yinyin attributed the short tenure of university presidents to the appointment and administration of principals in China. In a comprehensive view, there is no systematic study on the influence of the selection method on the tenure of university presidents, and the direction of the study is also pointed out.

Age of employment. In Liu Xiuli's study [43], they thought that American University President rejuvenation is the reason for a longer term, and the President of China's most 50-yearold to get the principal post, the general "aging", by the age limit of retirement, even if the excellent headmaster will not have too long tenure. Chen Hong [44], who studied the principals of private universities in China, found that their term of office was generally short and lower than the average term of public schools, mainly because of the high age of such university presidents, which was related to the source of the principals of private universities.

In addition, there are many influential factors on the selection and appointment system of university presidents, and some scholars have studied them. For example, in the research of Zhang Xin etc [38], they believe that the factors that influence the tenure of American university presidents are the background of the Times and the cultural and religious nature. Yu Ying etc. [45], by combing the research on the tenure system of university presidents in the past 20 years, it is found that the reasons for the short term of the university presidents are unclear, the rules of the session are unclear, and the outgoing mechanism is relatively weak.

\section{Result}

\subsection{Advantages of Agent Selection Mechanism}

The principal selection mechanism with diversified subjects is more democratic and scientific. The principal's idea of school governance conforms to the requirements of school development, and is also conducive to mobilizing the participation of the main body of faculty and staff to jointly promote the development of the school.

\subsection{Key Assessment Factors for Candidates}

Principal candidates should pay attention to their academic background, social science literacy and diversified professional experience. All these will actively promote the professionalization of university presidents.

\subsection{Advantages of Stable Tenure}

Stable tenure can well implement the President's long-term development plan, which is conducive to the long-term and stable development of the school.

\section{Discussion}

\subsection{The Disadvantages of a Fully Democratic Electoral System}

Must a fully democratic system of President selection be perfect? In fact, there are some disadvantages. For example, the whole election process is noisy and can become a stage of inter-school rivalry and party competition. Which will cause the bad election culture to invade the campus.

\subsection{Characteristics of Government Appointment System}

The government appointment system is generally carried out in a relatively closed state, brewing and discussing within a small scope, which is less affected by various aspects of society, but has significant government behavior characteristics, too strengthened administrative attributes of colleges and universities, and the lack of sense of ownership of the faculty and staff, increasing the improper dedication of personnel.

\subsection{The Electoral System Should Be Reformed to Improve It}

Different countries have different national conditions, and people have different understandings of the President 
selected system. It cannot exactly replicate the way elections are conducted in other countries. But in the selection process exposed serious shortcomings, should we try to reform it? I think it's needed.

\section{Conclusion}

The famous British scholar AshBI once said, "any kind of university is the product of heredity and environment." So is the selection system for university presidents. The selection of university presidents should not be separated from a country's specific political and economic systems and cultural traditions. However, the analysis of the successful experience and failure lessons in the selection of university presidents at home and abroad can provide reference for us.

\subsection{The Principal Should Be a Full-time Administrator}

Universities have their own characteristics, and presidents should be selected as full-time administrators.

\subsection{Elections and Administrative Appointments Should Be Combined}

Professors or members of the academic committee of the university shall have certain voting rights in the selection of the President. Try to teach a combination of elections and administrative appointments.

\subsection{We Need to Expand the Autonomy of Colleges and Universities}

We should improve educational laws and regulations and expand the autonomy of universities in running their own schools. From the government's point of view, universities will not lose their control if they conduct elections within a certain scope. From the perspective of the university, relevant members of the university have certain voting rights in the selection of the President, which can make the President more accountable to the university, teachers, students and staff.

\section{Fund Project}

Jiangsu university philosophy and social science foundation project: study on the effectiveness of ideological and political theory course in independent colleges from the perspective of socialist core value system (2017SJB2171).

\section{References}

[1] Zhu Hongqi. Towards the specialization of principals [J]. Educational Research.

[2] Guo Jun, Ma Wanhua. An empirical study on the group characteristics of American University presidents--a perspective based on the background of history $[\mathrm{J}]$. Comparative education Research, 2013 (01): 17-21.
[3] Zhang Yingqiang, Suo Kaifeng,. Who's doing the research on the president of China's undergraduate university--a survey of college presidents' employment [J]. Higher education Research, 2016 (06): 12-25.

[4] Li Qiaozhen. Analysis of the characteristics of current principals in key universities in China--a case study of "211 Project" hundred Universities [J]. Higher education exploration, 2016 (03): 34-40.

[5] Xieqing. Three key issues in the selection of first-class university presidents $[\mathrm{J}]$. China University Science and Technology, 2014 (03): 26-28.

[6] Li Zhongwei Study on the personal characteristics of the current school principals in 985 Project [J]. University education Management, 2016 (04): 32-43.

[7] Wu Jian, The influence of educational background on the selection of university presidents from the quality of the presidents of foreign famous universities [J]. Higher education Research, 2010 (07): 105-109.

[8] Li Ping. The difference analysis of the principal selection system of American and Japanese public research universities [D]. Changchun: Jilin University, 2011: 10-20.

[9] Guo Jun, Sun Yu, Huangxin. The academic background of university presidents ' Education in China--a case study of 115 "211 Project" university Presidents [J]. Chinese higher Education Research, 2012 (08): 24-29.

[10] Zhu Jian. Study on the qualifications of university presidents in England--an interpretation based on five university presidents ' job postings [J]. Fudan Education Forum, 2014 (03): 18-23.

[11] Wang Jianjun, Weng Wanpingt. Study on the qualifications of university presidents in the United States--an interpretation of the six University Presidents ' selection announcement $[\mathrm{J}]$. Chongqing Higher Education Research, 2015 (1): 94-111.

[12] Ren Zhen. Study on the selection criteria and procedures of the top 70 university presidents in the world [D]. Jinan: Shandong University of Finance and Economics, 2013: 4757.

[13] Wang Min. The academic background of the incumbent principal of Taiwan Public University [J]. Journal of Lanzhou University (social Science Edition), 2012 (5): 159-163.

[14] Shang Guanjun, Guo Jun, Li Kai, Study on the professional background of Chinese university presidents--taking the 115 "211 Project" university presidents as an example [J]. Monthly Education, 2011 (11): 6-9.

[15] Zhong Binglin, Zhou Haitao. The principal selection mechanism of world-class universities and its revelation--a comparative study of Presidents ' Management in world-class universities $[\mathrm{J}]$. Journal of the National Institute of Educational Administration, 2011 (08): 6-14.

[16] Liu Weina. A comparative study on the selection mechanism of the presidents of public universities in Taiwan [D]. Xi ' an: Shaanxi Normal University, 2011: 25.

[17] Qian Peizhong, Li Yingying. Historical changes of the standard and social image of university presidents in China [J]. Jiangsu Higher Education, 2013 (4): 25-28. 
[18] Ji Chengjun. A comparative analysis of the university presidents selection in China and abroad [J]. Chinese Science and Technology Awards, 2013 (08): 24-27.

[19] Tangjian, Chen Yan. The selection of university presidents: Practice and thinking--based on the comparative study between America and China [J]. Higher education development and Assessment, 2012 (2): 26-31.

[20] Xiong Wanxi. University President Selection: The experience of top American universities--an interview with Derek bOK, former president of Harvard University [J]. Modern university education, 2013 (5): 18-22.

[21] Xiong Wanxi. Study on the selection process of world-class university presidents--a case of 2004 years of MIT President Selection [J]. Modern university education, 2014 (1): 63-67.

[22] Qi Pinwei, Sun Hongzhi. The selection of British university presidents and the role of principals [J]. World Education information, 2008: 52-54.

[23] Ming Xin. A comparative study on the selection system of university presidents in the United States and Britain [J]. Coal higher Education, 2007 (1): 68-71.

[24] Chen Wei. The function and selection of university presidents in Britain [J]. Chinese higher Education, 2014 (5): 61-63.

[25] Fu Lianxing. International comparative Study on the selection and appointment of university presidents [J]. Journal of Linyi Teachers College, 2017 (2): 116-118.

[26] Chen Yan. Research on the reform of the selection and appointment system of Chinese university presidents [D]. Yangzhou: Yangzhou University, 2011: 30-35.

[27] Zhong Binglin, Zhou Haitao, the principal selection mechanism of world-class universities--a comparative study of Presidents ' Management in world-class universities [J]. Journal of the National Institute of Educational Administration, 2011 (8): 6-14.

[28] Sun Jin. How to elect the headmaster of German top universities--case study of Heidelberg University [J]. Comparative education Research, 2014 (3): 7-12.

[29] Ma Huaide. Presidential selection system and governance structure of European universities [J]. Education Research, 2011 (2): 104-109.

[30] Zhang Jinwei. The improvement of the open selection procedure of Chinese university presidents [J]. Shanghai Education Evaluation Research, 2014 (3): 32-35.

[31] Zhang Yingqiang, suo Kaifeng, who is doing the president of Chinese undergraduate University--a survey of the current position of university presidents in China [J]. Higher education Research, 2016, 37 (06): 12-25.
[32] Chen Yan. The role, quality and scientific selection of Chinese university presidents in the Age of globalization [J]. Jiangsu Social Sciences, 2011 (5): 243-248.

[33] Yao Jinju. A study on the legal issues of the selection of public university principals [J]. Journal of the National Institute of Educational Administration, 2014 (5): 63-68.

[34] Xu Guodong. Research on the selection mechanism of modern universities in China [J]. Journal of the National Institute of Educational Administration, 2010 (6): 18-22.

[35] Yang Xinglin, how to select the university president in China-three emphasis on the angle of torture [J]. Chongqing Higher Education Research, 2016 (1): 96-114.

[36] Fan Xiaojie. Research on the selection mechanism of university principals under the perspective of "principalagent" relationship [J]. Exploration of higher Education, 2015 (1): $10-15$.

[37] Lin Zhaohong, Zhang Rui. The prospect of perfecting the mechanism of college President selection--a mixed view based on higher order theory and competency model [J]. UNESCO, 2013 (3): 1-14.

[38] Zhang Xin, zhang Meng. An analysis of the presidency of American Research Universities [J]. Heilongjiang Education (research and evaluation of higher education), 2017 (6): 80-83.

[39] Liu Xiuli, zhang Junhui. Comparative study on the tenure of Chinese and foreign university presidents $[\mathrm{J}]$. Foreign education Research, 2007 (12): 72-76.

[40] Liu Siliang, Xia Quan. A study on the group characteristics of outgoing principals of nine School Alliance [J]. Modern university education, 2016 (3): 103-111.

[41] Chen Yinyin, Guan Hua. The status quo of university presidents ' tenure and suggestions for improvement--taking "985 universities" as an example [J]. Coal higher Education, 2016 (2): 23-122.

[42] $\mathrm{Yu}$ Xinan. Reforming the transformation of "public" to "private" in colleges and universities--from the average term of office of university presidents in China only 4.1 years [J]. Journal of Huanghe University of Science and Technology, 2009 (02): 3-6.

[43] Liu Xiuli, zhang Junhui. A comparative study of the tenure of university presidents in China and abroad [J]. Foreign education Research, 2007 (12): 72-76.

[44] Chen Hong, yuan Benhong. On the status quo and selection of principals of private universities in China [J]. Advanced Engineering Education Research, 2016 (4): 112-116.

[45] Yu Ying, Qin Cong. A review of the tenure system of university presidents in China [J]. Heilongjiang Education (research and evaluation of higher education), 2014 (6): 68-71. 